\title{
CAUCHY'S ERROR REPRESENTATION OF HERMITE INTERPOLATING POLYNOMIAL AND RELATED RESULTS
}

\author{
Gorana Aras-Gazić, Josip PeČArić And Ana Vukelić
}

Abstract. In this paper we consider convex functions of higher order. Using the Cauchy's error representation of Hermite interpolating polynomial the results concerning to the HermiteHadamard inequalities are presented. As a special case, generalizations for the zeros of orthogonal polynomials are considered.

Mathematics subject classification (2010): Primary 26D15; Secondary 26D07, 26 A51.

Keywords and phrases: $n$-convex function, Hermite interpolating polynomial, Hermite-Hadamard inequality, orthogonal polynomials.

\section{REFERENCES}

[1] R. P. Agarwal And P. J. Y. Wong, Error Inequalities in Polynomial Interpolation and Their Applications, Kluwer Academic Publishers, Dordrecht/Boston/London, 1993.

[2] G. Aras-Gazić, V. Čuljak, J. PeČarić And A. Vukelić, Generalization of Jensen's inequality by Lidstone's polynomial and related results, Math. Ineq. Appl. 16 (4) (2013), 1243-1267.

[3] G. Aras-GaziĆ, V. Čuljak, J. PeČArić And A. Vukelić, Generalization of Jensen's inequality by Hermite polynomials and related results, Math. Rep. 17 (67) (2) (2015), Article 4.

[4] G. Aras-Gazić, V. ČUlJak, J. PeČarić And A. Vukelić, Cauchy's error representation of Lidstone interpolating polynomial and related results, J. Math. Inequal. 9 (4) (2015), 1207-1225.

[5] M. Bessenyei AND Zs. PÁles, Higher-order generalizations of Hadamard's inequality, Publ. Math. Debrecen 61 (3-4) (2002), 623-643.

[6] S. Karlin, Total Positivity, Stanford Univ. Press, Stanford, 1968.

[7] J. E. PEČArić, F. Proschan AND Y. L. TONG, Convex functions, partial orderings, and statistical applications, Mathematics in science and engineering 187, Academic Press, 1992.

[8] T. Popoviciu, Sur l'approximation des fonctions convexes d'ordre superieur, Mathematica 10, (1934), 49-54. 